\title{
MNEs and wages: The role of productivity spillovers and imperfect labor markets is $^{2}$
}

\author{
Bahar Bayraktar Saglam ${ }^{\text {, }}$, Selin Sayek ${ }^{\mathrm{b}, *}$ \\ ${ }^{a}$ Hacettepe University, Turkey \\ ${ }^{\mathrm{b}}$ Bilkent University, Turkey
}

\section{A R T I C L E I N F O}

\section{Article history:}

Accepted 30 June 2011

\section{JEL classification}

F16

F23

J31

Keywords:

FDI spillovers

Wage spillovers

Imperfect labor markets

Firm wage premium

Wage dispersion

\begin{abstract}
A B S T R A C T
Disentangling the labor market implications of increased foreign capital flows remains important. This paper provides a unifying framework allowing to study the wage implications of multinational enterprise (MNE) activities, pointing to the importance of controlling for both labor market imperfections and productivity spillovers from foreign to local firms. Results show that increased MNE activities increase average wages in the local economy while contributing to a larger wage dispersion between the MNE and local firms. While the results pertaining to average wages depends heavily on the frictions in the labor market, how much the wage dispersion alters also depends on the extent of productivity spillovers from the MNEs to the local firms and the complementarity between domestic and foreign capital.
\end{abstract}

(c) 2011 Elsevier B.V. All rights reserved.

\section{Introduction}

The increasing prominence of Multinational Enterprises (MNEs) in the worldwide production activities over the past decades has generated significant interactions between them and the local firms. ${ }^{1}$ According to UNCTAD's, 2007 World Investment Report over the past two and a half decades the number of workers employed in the foreign affiliates of MNEs has increased threefold and represents around 3\% of worldwide employees. This ever-increasing presence of MNEs in global production is expected to create both productivity and wage spillovers. Indeed one would expect that productivity and wage spillovers from MNEs to local firms occur simultaneously, where the extent of both spillovers depends on each other. While the literature has focused on both spillovers independently, studies that take into account the possible interactions among the two spillovers are very few in number. Furthermore, in disentangling the labor market effects of increased foreign firm presence most of the studies have assumed perfectly competitive labor markets, ignoring possible frictions.

The following exercise seeks to identify the individual role played by the labor market imperfections and the extent of productivity spillovers on the wage spillovers from increased foreign firm

\footnotetext{
is The authors owe thanks to the anonymous referees and the participants of the ASSET conference, October 2009.

* Corresponding author at: Bilkent University, Department of Economics, Ankara Turkey. Tel.: + 903122901406 .

E-mail addresses: sbahar@hacettepe.edu.tr (B.B. Saglam), sayek@bilkent.edu.tr (S. Sayek).

${ }^{1}$ We use the terms foreign firms and multinationals interchangeably.
}

presence. The analysis not only allows to identify the wage spillovers from MNEs to domestic wages but also allows studying the wage premium paid by foreign firms under different extents of productivity spillovers and labor market imperfections. ${ }^{2}$ We construct a model where the productivity spillovers and labor market imperfections are explicitly modeled and we study three main questions: How do the absolute wages paid by foreign and local firms compare in cases with or without labor market imperfections and productivity spillovers from foreign firms? How does the foreign firm premium, defined as the ratio of the wages paid by foreign to those paid by local firms, differ across these models? Finally, does taking into account the labor market imperfections and productivity spillovers alter our expectations of how absolute wages and foreign firm premium change upon increased foreign direct investment (FDI)?

Ample studies have looked into the productivity spillovers from foreign to domestic firms, ranging from studies on Venezuela by Aitken and Harrison (1999), on Indonesia by Blomström and Sjöholm (1999) on the Czech Republic by Djankov and Hoekman (2000), on Lithuania by Javorcik (2004), on the US by Keller and Yeaple (2003) and on the UK by Haskel et al. (2007), among many others. Another strand of the literature has focused on the wage spillovers from foreign to domestic firms, including studies by Aitken et al. (1996), Feenstra and Hanson (1996) and Lipsey and Sjöholm (2004), among others. However, none of these studies look into the interactive role

\footnotetext{
2 We use the term foreign firm premium to capture the wage premium paid by the foreign firms. From this point on we will define it as the ratio of the wages paid by foreign firms to the wages paid by domestic firms.
} 
played by the two spillovers, and explicitly model the link between productivity spillovers, labor market imperfections and wage spillovers. This paper tries to fill this gap in the literature.

As identified by Aitken et al. (1996), Feenstra and Hanson (1996), and Lipsey and Sjöholm (2004), among others, foreign firms tend to pay different wages than domestic firms. While studies by Driffield and Girma (2003), Conyon et al. (2002), Martins (2004), Aitken et al. (1996) document the foreign firm premium to be greater than one, where the foreign firms pay higher wages than domestic firms, Lipsey and Sjöholm (2004), Almeida (2007), Barry et al. (2005) and Girma et al. (2001) suggest that this is not always the case, there are instances where the domestic firm pays higher wages than foreign firms do. ${ }^{3}$ In the following exercise we study the role played by labor market imperfections and the extent of productivity spillovers in influencing the level of the foreign firm premium, as well as how the foreign firm premium evolves when the MNEs activities in the host country increase.

In summary, taking cue from the void in this literature, the following analysis shows the importance of taking into account both the extent of productivity spillovers and the labor market imperfections when studying wage spillovers. In this manner, this study is closely related to Barry et al. (2005) who explicitly study the counteracting roles of productivity spillovers and labor-poaching activities of MNEs in generating wage spillovers and also allow for frictions in labor markets but unlike this paper they do not formally model for these imperfections in the labor market. The below analysis adds to this framework by formalizing the imperfections in the labor markets by use of search models. ${ }^{4}$ Using a very basic search model framework we are able to shed light onto the three questions we pose.

Results point to the important role played by the labor market imperfections and productivity spillovers in all three aspects. Results suggest that, when labor market imperfections are taken into account upon increased FDI average wages in the economy will increase, where both foreign and domestic firms pay higher wages. Therefore the model supports the idea that foreign direct investments (FDI) create wage spillovers, where increased foreign firm presence increases wages paid by domestic firms. However, the dispersion in wages between those paid by foreign and local firms, i.e. the foreign firm premium, is altered upon increased MNE activities. While the former result is independent of whether or not there are any productivity spillovers from foreign to domestic firms, the extent of the change in the wage dispersion critically depends on the extent of productivity spillovers. The higher the extent of productivity spillovers less is the change in the foreign firm premium (or in other words less the change in wage dispersion). This theoretical finding has a significant bearing on the empirical literature that seeks to identify the wage effects of increased FDI. The framework points to the importance of controlling for the labor market imperfections in empirical estimation of the impact of increased MNE activities on wages. Reduced form estimation equations based on this unifying framework should ensure that when estimating the link between local or foreign firm wages and FDI one controls for both the local and foreign firm productivities, both the domestic and the foreign firm capital stock, and final good prices. As such, this framework points to important omitted variables in many of the existing empirical wage studies linking FDI and wages, and it explains why wages, both absolute and relative, differ in level across countries and in how they change after increased FDI.

The rest of the paper is structured as follows. The model is discussed in Section 2, results are presented in Section 3 and Section 4 concludes.

\footnotetext{
${ }^{3}$ See Ruane and Uğur (2004) for a discussion of the reasons for why there may exist a foreign firm premium.

${ }^{4}$ Bayraktar Saglam and Sayek (forthcoming) construct an encompassing framework in studying the wage gap between skilled and unskilled labor as well as domestic and foreign firm workers taking into account labor market frictions.
}

\section{The model}

\subsection{Main assumptions}

All agents are risk-neutral, infinitely-lived and discount the future at the common rate $r$. The economy is populated by a continuum of workers with the measure normalized to one. There are two types of jobs, foreign and domestic. The productivity of these jobs depends on the type of capital, whether or not it is a domestic or foreign firm. The productivity in each firm is denoted by $A_{i}, i=D, F$ where $D$ stands for domestic firms and $F$ stands for foreign firms. The amount of output produced in the domestic and foreign jobs with different types of workers is denoted as follows: ${ }^{5}$

$y_{i}=A_{i} k_{i}^{\alpha_{i}}, \quad i=F, D$

where $k_{i}$ stands for the capital. The level of technology in the domestic firms can increase with higher foreign firm presence due to possible productivity spillovers, $A_{D}=A k_{F}^{\gamma}$. The parameter $A$ denotes the domestic firm's productivity net of the foreign firm's spillovers, whereas $\gamma$ denotes the extent of productivity spillovers from the foreign capital, $k_{F}{ }^{6}$ In this model increased foreign firm presence is measured as increased amounts of foreign capital used in the production by foreign firms, i.e. higher values of $k_{F}$, which itself is endogenously determined.

The revenue of foreign and domestic firms net of non-worker costs is as follows:

$R_{i}=p_{i} y_{i}-p_{k i} k_{i}, \quad i=F, D$

where $p_{i}$ is the price of the final good produced by firm $i, y_{i}$ is the output produced by firm $i, p_{k i}$ is the price of the capital used by firm $i$ and finally $k_{i}$ is the capital used by firm $i$. The price of capital, $p_{k i}$, is also modeled as different across firms, where one can envisage the differences being due to the nature of FDI which inherently has more intangible assets incorporated in it than the domestic firm capital stock.

Once a firm hires a worker, it rents capital in a perfectly competitive market, where the profit maximizing amount of capital is determined by it being paid its marginal revenue product ${ }^{7}$ :

$k_{i}=\left(\frac{p_{i} \alpha_{i} A_{i}}{p_{k i}}\right)^{1-\alpha_{i}}$

According to Eq. (3) we can model increased FDI via an exogenous increase in any one of the following variables: $p_{F}, p_{k F}, \alpha_{F}$ or $A_{F}$.

\subsection{Matching}

Job seekers and firms with vacant jobs are matched in pairs through an imperfect matching technology. The total flow of contracts between a job seeker and a firm is determined by a standard constant returns to scale matching function, $m\left(v_{D}+v_{F}, u\right)$, where $v_{D}$ and $v_{F}$ stands for the mass of domestic and foreign vacancies, respectively and $u$ is the mass of unemployed workers. $\eta=\frac{v_{D}}{v_{D}+v_{F}}$ denotes the fraction of vacancies posted by domestic firms. The labor market tightness is denoted by $\theta=\frac{v_{D}+v_{F}}{u}$. The rate at which firms meet a

\footnotetext{
5 See Davidson et al. (2008) for a similar depiction.

${ }^{6}$ This is based on the evidence provided by several studies regarding the positive productivity spillovers of FDI, see Javorcik (2004) and Barry et al. (2005).

${ }^{7}$ This modeling can be interpreted as either the firms explicitly renting capital from the market or implicitly charging such a price for the their internal transactions on their income statement.
} 
job-seeker is equal to $\frac{m(\theta)}{\theta}$; workers may meet a job at rate $m(\theta)$. The matching rate of workers (firms) is increasing (decreasing) in $\theta$.

\subsection{Firms}

The value of employing a worker for each firm is $J_{i}$, for $i=F, D$ :

$r J_{i}=R_{i}-w_{i}-\delta J_{i}$

where $w_{i}$ denotes the workers' wage in the foreign and domestic firms, respectively, for $i=F, D$, and the job destruction rate is exogenous, $\delta$.

The asset values of workers, $W$, in each firm is:

$r W_{i}=w_{i}-\delta\left(W_{i}-U\right), \quad i=F, D$

The asset value of unemployed workers, $U$, is:

$r U=m(\theta)\left[\eta\left(W_{D}-U\right)+(1-\eta)\left(W_{F}-U\right)\right]$

where the unemployed worker could become employed in the domestic firm with a certain probability, which depends on the matching probability $m(\theta)$ and the extent of vacancies created by the domestic firms $\eta$, and could increase their asset value from $U$ to $W_{D}$. Or the unemployed worker could match with a foreign firms, whose probability depends on $m(\theta)$ and $(1-\eta)$ and increase their asset value from $U$ to $W_{F}$.

The values of vacancies $V_{i}$ for $i=F, D$ are:

$r V_{i}=-c_{i}+\frac{m(\theta)}{\theta}\left(J_{i}-V_{i}\right)$

A firm who posts a vacancy must pay a recruitment cost of $c_{i}$, for $i=D, F$. Given free entry, all profit opportunities from posting vacancies are exploited; hence, in equilibrium, $V(D)=V(F)=0$. The steady state equilibrium conditions require that flows into and out of the employment state must be equal and this condition is given by:

$\delta(1-u)=m(\theta) u$

Eq. (8) suggests that the unemployment rate in the economy depends positively on the exogenous rate of job destruction, $\delta$, and negatively on the rate at which workers meet a job $m(\theta)$ (which endogenously and positively depends on the extent of job vacancies posted by domestic and foreign firms, $v_{D}$ and $v_{F}$ respectively). ${ }^{8}$

\subsection{Wages}

The Generalized Nash Bargaining Solution is widely used in matching models of the labor market. In this context, wages are given by ${ }^{9}$

$w_{i}=\beta R_{i}+(1-\beta) r U, \quad i=F, D$

\footnotetext{
8 The unemployment rate is endogenously determined in this framework in equation (8), which is a value added to the framework of Barry et al. (2005) who model labor market imperfections exogenously. By allowing both productivity spillovers and labor market frictions, FDI reduces unemployment rate if there are constant returns to scale in the domestic firm. Due to the existence of productivity spillovers, the output of the domestic firms becomes $y_{D}=A k_{F}^{\gamma} k_{D}^{\alpha_{D}}$. The FDI lowers the unemployment rate under constant returns to scale assumption, $\gamma+\alpha_{D}=1$ in the current case.

9 The standard match requirement condition of search models requires that the total surplus is always positive, where total surplus (S) equals to the $S=W_{i}-U+J_{i}-V_{i}$ i.e. $W_{i}-U+J_{i}-V_{i} \geq 0$. The solution detailed in the following discussion exists under this condition. The proof is available from the authors upon request.
}

where $\beta$ is the bargaining power of the workers. Using Eq. (5) for $i=F$, $D$, we can derive the asset value of unemployed workers discounted, $r U$, as follows:

$r U=\frac{m(\theta) \beta\left[\eta R_{D}+(1-\eta) R_{F}\right]}{r+\delta+\beta m(\theta)}$

Using Eqs. (2), (9) and (10) we find the wages paid by foreign and domestic firms, respectively, as follows:

$w_{D}=\beta\left(1-\alpha_{D}\right) P_{D} A_{D} k_{D}^{\alpha_{D}}+\frac{(1-\beta) m(\theta) \beta\left[\eta\left(1-\alpha_{D}\right) P_{D} A_{D} k_{D}^{\alpha_{D}}+(1-\eta)\left(1-\alpha_{F}\right) P_{F} A_{F} k_{F}^{\alpha_{F}}\right]}{r+\delta+\beta m(\theta)}$

$w_{F}=\beta\left(1-\alpha_{F}\right) P_{F} A_{F} k_{F}^{\alpha_{F}}+\frac{(1-\beta) m(\theta) \beta\left[\eta\left(1-\alpha_{D}\right) P_{D} A_{D} k_{D}^{\alpha_{D}}+(1-\eta)\left(1-\alpha_{F}\right) P_{F} A_{F} k_{F}^{\alpha_{F}}\right]}{r+\delta+\beta m(\theta)}$

Eqs. (11) and (12) show that the wages paid are a weighted average of the value the worker generates for the firm (the first term) and the value of the reservation wage of the worker (the second term). The weights are determined by the bargaining power of the worker, $\beta$. This is a standard feature of the search models, showing that the wage determination does not solely depend on the marginal revenue product of the worker but also on the alternative average wage of the worker if it were to leave the job, fall into the unemployment pool and eventually get matched with a foreign or domestic firm. The latter term of both equations captures this phenomenon, where the reservation wage is an average wage the worker could get from foreign and domestic firms.

The important role played by the imperfections of the labor market is evident in both equations. If the labor markets were modeled as perfectly competitive, wages would only be equal to the marginal revenue product of the labor, where $\beta=1$, and the latter term in both equations would drop out. ${ }^{10}$

\section{Results}

Despite the simplicity in comparing the wage equations with and without labor market imperfections comparing the levels and changes of the wages, in other words comparing their magnitudes is not that straightforward. We are able to study four cases, each a combination of different labor market imperfections and productivity spillovers. These four cases are summarized in Table 1. Below we discuss these results in detail, where we start with comparing the wages across these four cases and follow the discussion with the effects of increased FDI on absolute and relative wages under these four alternative cases.

\subsection{Ranking wages}

\subsubsection{Absolute wages}

Using Eq. (9) we are able to compare the levels and changes of the wages with and without labor market imperfections and productivity spillovers. The standard match requirement condition of search models requires that the total surplus is always positive, i.e. $W_{i}-U+J_{i}-V_{i} \geq 0$. This condition allows for the ranking of absolute wages across different scenarios.

Let's start with case 1 , where the labor markets are perfectly competitive and there are no productivity spillovers from foreign to domestic firms. In this case the wages, as depicted in Eqs. (11) and (12) will simplify to where the wages paid by the firms are equal to the marginal productivity of the worker. This would be the case even

\footnotetext{
10 This unifying framework provides support to including alternative wages in estimation equations of wages, such as the study of Driffield and Girma (2003) among many others.
} 
Table 1

Summary of findings.

\begin{tabular}{lllll}
\hline & 1 & 2 & 3 & 4 \\
\hline Labor market imperfections & No & No & Yes & Yes \\
Productivity spillovers & No & Yes & No & Yes \\
$w_{F}$ & $w_{F}^{1}=w_{F}^{2}>w_{F}^{4}>w_{F}^{3}$ & & \\
$w_{D}$ & $w_{D}^{2}>w_{D}^{1}$ and $w_{D}^{4}>w_{D}^{3}$ & and $w_{D}^{2}>w_{D}^{4}$ \\
$\frac{w_{F}}{w_{D}}$ & $\frac{w_{F}^{1}}{w_{D}^{1}}>\frac{w_{F}^{2}}{w_{D}^{2}}>\frac{w_{F}^{3}}{w_{D}^{3}}>\frac{w_{F}^{4}}{w_{D}^{4}}$ & & \\
$\frac{\partial w_{F}}{\partial k_{F}}$ & $>0$ & $>0$ & $>0$ & $>0$ \\
$\frac{\partial w_{D}}{\partial k_{F}}$ & $=0$ & $>0$ & $>0$ & $>0$ \\
$\partial \frac{w_{F}}{w_{D}}$ & $>0$ & $\lesseqgtr$ & & \\
$k_{F}$ & & & & \\
\hline
\end{tabular}

if we allowed for productivity spillovers from the foreign firms to the domestic firms, case 2. In other words, regardless of the extent of productivity spillovers between MNEs and local firms, when there are no imperfections in the labor market the workers earn their marginal productivity. However, even though the extent of productivity spillovers do not generate a discrepency between the marginal revenue product of labor and its wage, it does influence the marginal productivity of the domestic workers. ${ }^{11}$ When there are productivity spillovers from foreign to domestic firms this increases the marginal revenue product of the workers for domestic firms, and hence increases their wages one-to-one. However, for the workers in foreign firms the extent of productivity spillovers does not influence their marginal productivity and therefore leaves wages paid by foreign firms unchanged from case 1 to case 2 . In other words: $w_{D}^{1}<w_{D}^{2}$ and $w_{F}^{1}=w_{F}^{2}$. The numbers in the superscripts refer to the cases, as defined in Table 1.

Case 3 is when the labor market has imperfections but there are no productivity spillovers. As is the case for most standard labor search models this set-up also leads to the worker accepting a lower wage than her productivity when there are labor market imperfections. ${ }^{12}$ As in most search models we also find that across our cases $w_{D}^{1}>w_{D}^{3}$ and $w_{F}^{1}>w_{F}^{3}$, combining this ranking with the above case we are able to rank across the first three cases: $w_{D}^{2}>w_{D}^{1}>w_{D}^{3}$ and $w_{F}^{1}=w_{F}^{2}>w_{F}^{3}$.

The last case, case 4 , is when there are both labor market imperfections and productivity spillovers. The existence of productivity spillovers, regardless of the labor market imperfections, will always create higher wages because the productivity of the worker improves. If the productivity spillovers are positive, then $w_{D}^{2}>w_{D}^{1}$ and $w_{D}^{4}>w_{D}^{3}$. The matching condition requirements allow us to rank wages in cases where there are and there are not labor market imperfections. Similar to the case of the foreign firms we are able to show that the wages paid by domestic firms when there are no labor market imperfections are greater than when there are labor market imperfections, then $w_{D}^{1}>w_{D}^{3}$ and $w_{D}^{2}>w_{D}^{4}$. While these two orderings allow somewhat of a ranking it is not possible to analytically solve for the ranking condition of the case where there are neither labor market imperfections nor productivity spillovers versus when both exist. The existence of search frictions in the labor market reduces the wages but on the other hand the productivity spillovers generate wage spillovers, contributing to increase the wages. The eventual outcome of the move from a case with perfectly competitive labor markets with no foreign firm productivity spillovers to one where labor markets are imperfect and there are spillovers from FDI depends on which of these to forces outweigh. In short, if the wage reduction due to the labor

\footnotetext{
11 There are no spillovers from domestic to foreign firms.

12 See Eckstein and van den Berg (2007) for a summary discussion comparing different search-bargaining models all leading to the wage being less than the marginal productivity of the worker.
}

market imperfection outweighs the gains due to productivity spillovers then $w_{D}^{2}>w_{D}^{1}>w_{D}^{4}>w_{D}^{3}$, otherwise $w_{D}^{2}>w_{D}^{4}>w_{D}^{1}>w_{D}^{3}$.

When there are labor market imperfections, on the other hand, the existence of productivity spillovers becomes a factor that influences the reservation wage of the worker, as it alters the wages paid by the domestic firms. Indeed, when there are labor market imperfections the wages paid by the foreign firm are larger when there are productivity spillovers, which in turn generate wage spillovers in the domestic firms. Using the match formation condition we are further able to rank wages paid by the foreign firm when there are and when there are not labor market imperfections. We show that the wages paid by the foreign firm are higher when there are no frictions in the labor market.

Proposition 1. In short, for wages paid by the domestic firms the following ranking is possible: $w_{D}^{2}>w_{D}^{1}$ and $w_{D}^{4}>w_{D}^{3}$ and $w_{D}^{2}>w_{D}^{4}$, where the comparison between $w_{D}^{2}$ and $w_{D}^{4}$ depends on whether labor market frictions dominate the productivity spillovers or not. Whereas for the wages paid by the foreign firms the ranking is as follows: $w_{F}^{1}=w_{F}^{2}>w_{F}^{4}>w_{F}^{3}$. In both cases the numbers in the superscripts refer to the cases defined in Table 1.

\subsubsection{Relative wages}

In addition to the absolute wages it is possible to also rank the foreign firm preimum (or the relative wages) across the four cases of interest. If the revenue of the foreign firm is higher than that of the domestic firm (see Eq. (2)) then the relative wages with no labor market imperfections are greater than when (keeping productivity spillovers unchanged) there are labor market imperfections, i.e. $\frac{w_{F}^{1}}{w_{D}^{1}}>\frac{w_{F}^{3}}{w_{D}^{3}}$ and $\frac{w_{F}^{2}}{w_{D}^{2}}>\frac{w_{F}^{4}}{w_{D}^{4}}$.

Ranking the cases with productivity spillovers requires assumptions about the share of foreign capital in foreign and domestic production, respectively (i.e. $\alpha_{F}>\gamma$ ). If this parametric condition holds and there are positive productivity spillovers from the foreign to the domestic firm, increasing the productivity of the domestic firm then the following relative wage ranking is observed: $\frac{w_{F}^{1}}{w_{D}^{1}}>\frac{w_{F}^{2}}{w_{D}^{2}}>\frac{w_{F}^{3}}{w_{D}^{3}}>\frac{w_{F}^{4}}{w_{D}^{4}}$. In short, the foreign firm premium falls when there are productivity spillovers and when labor markets have more imperfections.

\subsection{Effects of an increase in FDI}

We next discuss the effects of an increase in FDI, $k_{F}$, on the absolute and relative wages in the economy. Specifically we ask whether taking into account the labor market imperfections and productivity spillovers should alter how absolute wages and foreign firm premium change upon increased FDI.

\subsubsection{Absolute wages}

The channels through which increased FDI affects absolute wages are as follows:

1. An increase in foreign firm presence, i.e. higher $k_{F}$, raises the marginal revenue product of the worker in the foreign firm, directly raising the inside value of the worker to the firm and being reflected in higher wages for the worker in the foreign firm. All else constant this channel leads to: $\frac{\partial w_{F}}{\partial k_{F}}>0$.

2. If there are productivity spillovers from the foreign to local firms, higher rates of FDI improve the productivity of workers in the domestic firms and contributes to their wages via an improved marginal revenue product. All else constant, this channel leads to: $\frac{\partial w_{D}}{\partial k_{F}}>0$.

3. The increase in foreign firm wages increases the reservation wage for all the workers in the economy. This mechanism is due to the 
explicit modeling of labor market imperfections. All else constant, this channel leads to: $\frac{\partial w_{F}}{\partial k_{F}}>0$ and $\frac{\partial w_{D}}{\partial k_{F}}>0$.

This list allows a quick analysis of how wages respond to foreign capital across the four cases. When there are no labor market imperfections and no productivity spillovers only the first item in this list will be operational. Hence, in case 1, increased FDI will increase the wages paid by foreign firms, but will not influence the wages paid by domestic firms. In case 2, where there are no labor market imperfections but there are productivity spillovers, both the foreign and the domestic firms will enjoy increased marginal productivities of workers and in return will pay higher wages. In case 3 and 4, where there are labor market imperfections the last item above will be at work, where the reservation wages of all workers will increase, contributing to higher wages paid by both the foreign and the domestic firms. While the positive contribution of the hike in the reservation wages is observed in both cases 3 and 4 the two cases differ in the domestic wages, where the effect of FDI on domestic wages is expected to be higher in case 4 due to both this increase in the reservation wages and the productivity spillovers effect on the worker's marginal revenue product.

This discussion points to the separate role played by both the labor market imperfections and the extent of productivity spillovers in determining the elasticity of the average wages, and foreign and domestic wages individually, to increased FDI in the economy.

\subsubsection{Relative wages}

Given the differential quantitative effect of FDI on the level of domestic and foreign wages in all four cases it is of interest to identify in detail how the relative wages respond to increased foreign firm presence. In case 1 , where there are no labor market imperfections or productivity spillovers, increased FDI only influences the marginal productivity and hence wages of workers in the foreign firm, leaving the wages paid by domestic firms intact. As such the foreign firm premium definitely increases in case 1.

If there are productivity spillovers in perfectly competitive labor markets increased FDI will increase the marginal productivity, and in turn wages, of both the foreign and domestic firm workers. The extent to which foreign firm capital contributes to the marginal productivity of workers, in other words the share of foreign capital in the production function of both firms, determines how the relative wages will evolve. If the share of foreign capital in the production of the foreign firm, $\alpha_{F}$, is greater (less) than the extent of productivity spillovers, measured by the implicit share of foreign capital in domestic firm productivity $\gamma$, then the foreign firm premium increases (decreases) upon increased FDI in the host country. Therefore, in case 2 the qualitative and quantitative effects of increased foreign firm presence on the foreign firm premium depend on the production functions of and linkages between the two types of firms.

If however, there are no productivity spillovers but there are labor market imperfections then the qualitative results regarding the elasticity of the foreign firm premium to foreign capital are not different from case 1 . An increase in the foreign capital increases the marginal productivity of the foreign firm workers and directly contributes to the foreign firm wages. This increase in foreign firm wages in turn increases the reservation wages for the average worker in the economy, further contributing to higher domestic and foreign firm wages. The foreign wages change more than the domestic wages since for the domestic wages only the reservation wage channel is operational but for the foreign wages both the productivity and the reservation wage channels are operational. Hence an increase in FDI contributes to higher foreign firm premium in case 3 . However, the extent of labor market imperfections does affect the quantitative response of the foreign and domestic firm wages, and in turn the foreign firm premium.
In the broadest case, where there are both labor market imperfections and productivity spillovers (case 4), the three channels suggest that it is the extent of productivity spillovers, $\gamma$, and the share of capital in the domestic firms' production, $\alpha_{D}$, that determines how the wage dispersion will evolve (this is due to the interaction of the productivity term, $A_{D}$, and domestic capital, $k_{D}$ ). If the productivity spillovers are large enough, such that foreign and domestic capital implicitly show an increasing returns to scale, $\gamma+\alpha_{D}-1>0$, then the marginal revenue product of workers for domestic firms increase disproportionally more than those for foreign firms, reducing the wage dispersion or the foreign firm premium. If the domestic and the foreign capital provide a constant returns to scale production for the domestic firm, $\gamma+\alpha_{D}-1=0$, then the wage dispersion remains unchanged where the contribution of increased FDI to domestic and foreign wages are of equal amount. Finally, if productivity spillovers are so little that foreign and domestic capital implicitly show decreasing returns to scale, $\gamma+\alpha_{D}-1>0$, then the marginal revenue product of workers for foreign firms increases disproportionally more than those for domestic firms, increasing the wage dispersion or the foreign firm premium. Results point to the importance of discussing the complementarity between domestic and foreign capital, and the productivity spillovers in any wage spillover debate. ${ }^{13}$

Comparing the last row in Table 1 across cases shows that when there are no productivity spillovers, regardless of the labor market imperfections, increase in FDI increases the relative wages. This is to suggest that the labor market conditions do not qualitatively play a role in the elasticity of the absolute and relative wages to FDI but does quantitatively affect the magnitude of this elasticity across the four cases. On the contrary, the cases where there are productivity spillovers point out the importance of taking into account the complementarity of domestic and foreign capital, as well the respective role of foreign capital in domestic versus foreign production, where the productivity spillovers affect the elasticity across the four cases both qualitatively and quantitatively.

In short, an increase in foreign firm presence, i.e. higher $k_{F}$, raises the marginal revenue product of the worker in the foreign firm, directly raising the inside value of the worker to the firm and being reflected in higher wages for the worker in the foreign firm. The increase in foreign firm wages increases the outside option value for all the workers in the economy, including those in the foreign firms as well those in domestic firms. The increase in the value of the outside option positively contributes to all wages in the economy, where both the foreign and the domestic firms pay higher wages to the workers. The latter mechanism is sheerly on account of the explicit modeling of labor market imperfections and the possibility of moving into and out of the unemployment pool. An additional channel for domestic wages is on account of the productivity spillovers from the foreign to local firms, which reinforces the positive link between FDI and increased wages paid by domestic firms. Higher rates of FDI improve the productivity of workers in the domestic firms and contributes to their wages via an improved marginal revenue product. ${ }^{14}$

\footnotetext{
${ }^{13}$ This is in line with the recent discussion of the importance of discussing the complementarity between capitals in the productivity spillover debate. See Alfaro et al. (2010) among others.

14 The important role played by productivity spillovers is also evident in how the extent of productivity spillovers influence the relative wages. Higher the productivity spillovers from foreign to domestic firms lower the wage dispersion, or the foreign firm premium, $\frac{\partial \frac{W_{F}}{w_{D}}}{\partial \gamma}\langle 0$. The higher the productivity spillovers from foreign to domestic firms the less the discrepency in the marginal revenue product of labor working for either firm. Given that the outside value term in wage determination does not differ across the workers in the two firms the major determinant of the wage dispersion is the relative marginal revenue product, which heavily relies on the extent of productivity spillovers in the local economy.
} 
Proposition 2. Foreign capital raises the foreign and domestic wages, $\frac{\partial w_{F}}{\partial k_{F}}>0$ and $\frac{\partial w_{D}}{\partial k_{F}}>0$.

Proposition 3. The effect of foreign capital on the wage dispersion (i.e. foreign firm premium) depends on the productivity spillovers, the production function of the local firm and the labor market imperfections. If there are no productivity spillovers, then regardless of the labor market imperfections the relative wages increase upon increased FDI. While the labor market imperfections do not affect the sign of this relationship it does influence the magnitude of the derivative. When there are spillovers the role of foreign capital in the domestic and foreign production or the complementarity between domestic and foreign capital becomes critical in determining the effects of FDI on relative wages, with the former being critical when labor markets are perfectly competitive and the latter being critical when there are labor market imperfections. As such it is clear that both labor market imperfections and productivity spillovers affect the qualitative and quantitative effects of FDI on wages.

The role played by the complementarity of the domestic and foreign capital in the results is clear in the analytical solution. It is possible to further observe this result in a numerical exercise. Since the foreign capital, $k_{F}$, is endogenously determined in the model the numerical exercise requires a change in an exogenous factor that will lead to higher FDI in the model. According to Eq. (3) exogenous changes in the productivity measure can be a factor that leads to increased FDI. As such we undertake the exercise of changing the productivity parameter and observing the evolution of absolute and relative wages at different levels of productivity spillovers. We carry out the exercise for the case where there are labor market imperfections, given the parametric dependence of the results in these cases.

The parameters are calibrated to match existing studies in the literature. Our goal is to discuss the effects of a change in the extent of foreign firm activity and not to match the results one-to-one with any specific economy. The baseline parameters are set as follows: $r=0.05$, $\beta=0.5, \delta=0.2, c_{D}=0.1, c_{F}=1.15, \alpha_{F}=0.5, \alpha_{D}=0.4, p_{i}^{K}=p_{i}=1$, $A_{F}=1.65$, and $A=1.1$. All these parameter values are reasonable and in line with the other studies including Albrecht and Vroman (2002), Gautier (2002) and Dolado et al. (2003). Below we detail some of these parameters that are specifically important for our discussions.

A novel dataset compiled by Morisset and Neso (2002) suggests that foreign firms face much larger costs than local firms do in terms of administrative barriers, ranging from being 12 times larger in India to twice as large in Argentina. Following this evidence it seems reasonable to assume that foreign jobs are more costly to create than local jobs, i.e. $c_{F}>c_{L}$. The choice of the absolute levels of these two costs follow a range of models including those by Faggio and Konings (2003), Hammermesh (1993), Russo et al. (2005) and Vanhala (2004).

The productivity gap between foreign and local firms, $\frac{A^{F}}{A}$ is assumed to be around $50 \%$. This assumption is based on a rich literature that suggests the productivity gap between foreign and local firms ranges from $10 \%$ to $100 \%$ (see Conyon et al., 2002; Kimura and Kiyota, 2007, among others). The interest rate is $5 \%$ and job destruction rate is 0.2 . For simplicity the prices are all normalized to 1 .

The exercise allows for identification of how the absolute and relative wages change as FDI increases (in this case as the foreign productivity parameter $A_{F}$ increases) across different cases of complementarity between domestic and foreign capital as well as different extent of productivity spillovers. Fig. 1a through c lends supporting evidence to the propositions of the analytical solution. The numerical simulation results, where the effects of a change in foreign capital on the market tightness and the vacancy distribution are taken into account, reiterates our above findings. Increased foreign capital (due to an exogenous productivity improvement) increases wages paid by both foreign and domestic firms, increasing the average wage
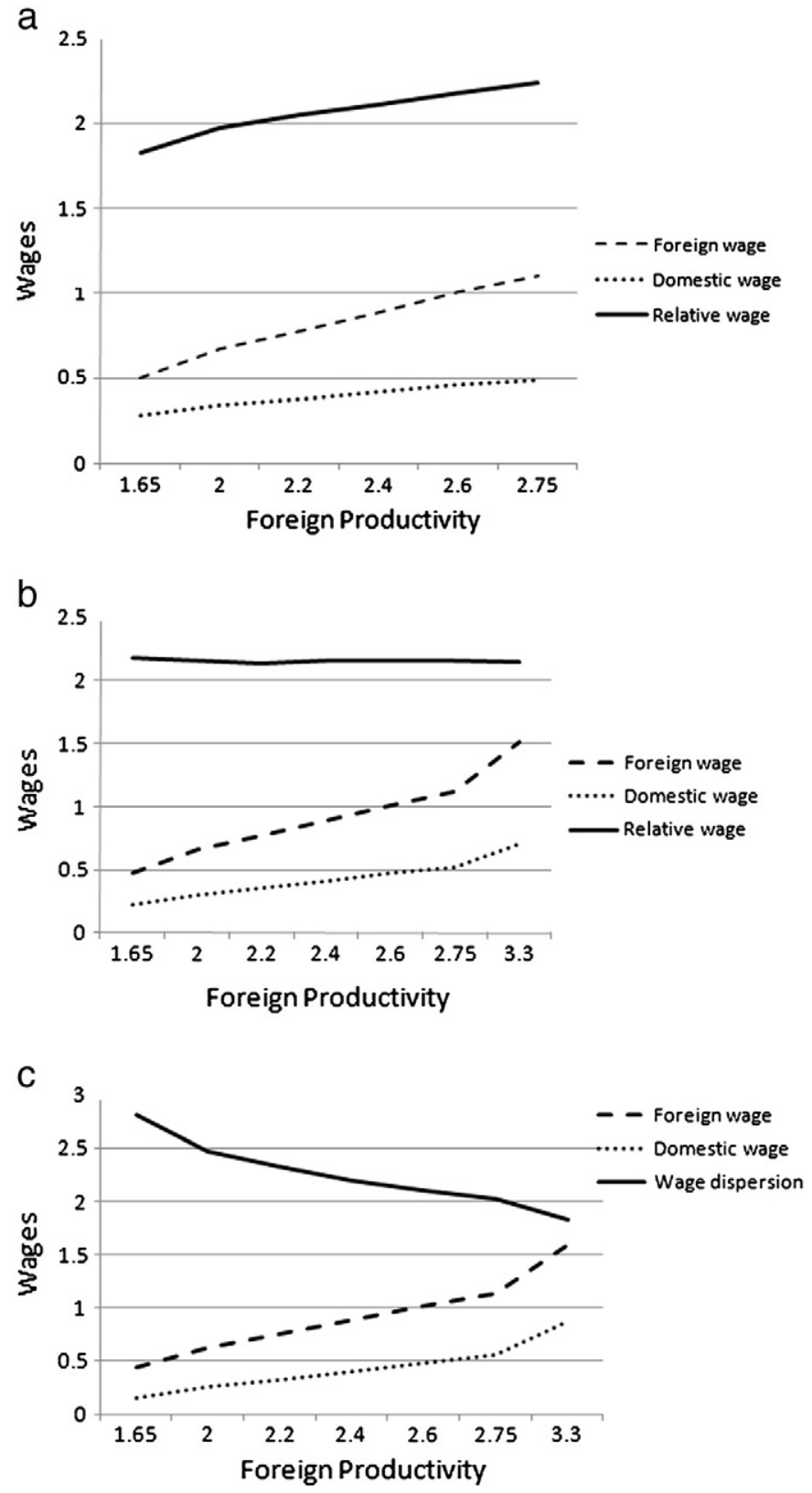

Fig. 1. a. Increasing returns to scale. b. Constant returns to scale. c. Decreasing returns to scale.

(except for when there are no spillovers - where domestic wage decreases). Secondly, the evolution of relative wage depends on the productivity spillovers and the returns to scale of domestic firm production: when foreign and domestic capital show increasing returns to scale features then relative wage decreases, when they show constant returns to scale features relative wage is unchanged, and finally when they show decreasing returns to scale features relative wage increases. ${ }^{15}$ In short, the numerical exercise confirms that all the propositions put forth in the analytical framework holds.

\footnotetext{
15 The results shown in the figures are qualitatively independent from the relative cost of filling a vacancy assumption across the domestic and foreign firms. However, we observe that the relative wage results also remain quantitatively unchanged if these costs are altered without changing their relative values. If all else constant the cost of filling a local (foreign) job increases then relative wages will increase (decrease).
} 


\section{Conclusions}

A unifying theoretical framework which incorporates realistic labor market imperfections and productivity spillovers is constructed to study the wage implications of increased FDI. Wage determination follows a usual search model framework where the workers can move from being unemployed to being employed in either a domestic or a foreign firm. Frictions in the labor mobility point to a wage determination in both domestic and foreign firms as a weighted average of the marginal revenue product of the worker and the reservation wage, where the weights depend on the labor market imperfections. The framework points to the important role played by the labor market frictions, how these frictions evolve with FDI and the productivity spillovers and complementarity of domestic and foreign capital in the determination of the average and relative wage implications of FDI. This result points to the importance of a codiscussion of productivity and wage spillovers, and a discussion within a framework that takes labor market imperfections into account. The empirical specifications testing for the wage effects of globalization should be based on the final equations from such a unifying framework to avoid omitted variable biases.

\section{References}

Aitken, Brian J., Harrison, Ann E., 1999. Do domestic firms benefit from direct foreign investment? Evidence from Venezuela. The American Economic Review 89 (3), 605-618.

Aitken, B.J., Harrison, A.E., Lipsey, R.E., 1996. Wages and foreign ownership. A comparative study of Mexico, Venezuela, and the United States. Journal of International Economics 40, 345-371.

Albrecht, J., Vroman, S., 2002. A matching model with endogenous skill requirements. International Economic Review 43, 283-305.

Alfaro, L., Chanda, A., Kalemli-Ozcan, S., Sayek, S., 2010. How does foreign direct investment promote economic growth? Exploring the effects of financial markets on linkages. Journal of Development Economics 91, 245-253.

Almeida, R., 2007. The labor market effects of foreign owned firms. Journal of International Economics 72, 75-96.

Barry, Frank, Görg, Holger, Strobl, Eric, 2005. Foreign direct investment and wages in domestic firms in Ireland: productivity spillovers versus labor-market crowding out. International Journal of the Economics of Business 12 (1), 67-84.

Bayraktar Saglam, Bahar and Selin Sayek, 2011. Skill and Foreign Firm Premium: Labor Market Effects of Multinational Enterprises, in Industrial Dynamics, Innovation Policy and Economic Growth through Technological Advancements edited by Erkan Erdil, forthcoming.
Blomström, Magnus, Sjöholm, Fredrik, 1999. Technology transfer and spillovers: does local participation with multinationals matter. European Economic Review 43 (4-6), 915-923.

Conyon, M., Girma, S., Thompson, S., Wright, P., 2002. The impact of foreign acquisition on wages and productivity in the U.K. The Journal of Industrial Economics 85-102.

Davidson, Carl, Matusz, Steven J., Shevchenko, Andrei, 2008. Globalization and firm level adjustment with imperfect labor markets. Journal of International Economics 75 (2), 295-309.

Djankov, Simeon, Hoekman, Bernard, 2000. Foreign investment and productivity growth in Czech enterprises. The World Bank Economic Review 14 (1), 49-64.

Driffield, Nigel, Girma, Sourafel, 2003. Regional foreign direct investment and wage spillovers: plant level evidence from the UK electronics industry. Oxford Bulletin of Economics and Statistics 65 (4), 453-474.

Dolado, Juan, J., Jansen, M., Jimeno, J.F., 2003. On-the-job search in a matching model with heterogeneous jobs and workers. IZA Discussion Papers 886.

Eckstein, Zvi, van den Berg, Gerard J., 2007. Empirical labor search: a survey. Journal of Econometrics 136 (2), 531-564.

Faggio, G., Konings, J., 2003. Job creation, job destruction and employment growth in transition countries in the 90s. Economic Systems 27, 129-154.

Feenstra, R.C., Hanson, G.H., 1996. Foreign investment, outsourcing and relative wages. In: Feenstra, R.C., Grossman, G.M., Irwin, D.A. (Eds.), The Political Economy of Trade Policy: Papers in Honor of Jagdish Bhagwati. MIT Press, pp. 89-127.

Gautier, P.A., 2002. Search externalities in a model with heterogeneous jobs and workers. Economica 273, 21-40.

Girma, S., Greenaway, D., Wakelin, K., 2001. Who benefits from foreign direct investment in the UK? Scottish Journal of Political Economy 48, 119-133.

Hammermesh, D.S., 1993. Labor Demand. Princeton University Press, NJ.

Haskel, Jonathan E., Pereiera, Sonia C., Slaughter, Matthew J., 2007. Does inward foreign direct investment boost the productivity of domestic firms? The Review of Economics and Statistics 89 (3), 482-496.

Javorcik, Beata, 2004. Does foreign direct investment increase the productivity of domestic firms? In Search of spillovers through backward linkages. The American Economic Review 94 (3).

Keller, Wolfgang, Yeaple, Stephen R., 2003. Multinational enterprises, international trade and economic growth: firm level evidence from the United States. Working Paper No. 9504. National Bureau of Economic Research, Cambridge, MA.

Kimura, F., Kiyota, K., 2007. Foreign-owned versus domestically-owned firms: economic performance in Japan. Review of Development Economics 11, 31-48.

Lipsey, Robert E., Sjoholm, Fredrik, 2004. Foreign direct investment, education and wages in Indonesian manufacturing. Journal of Development Economics 73 (1), 415-422.

Martins, P., 2004. Do foreign firms really pay higher wages? Evidence from different estimators. IZA Discussion Paper No. 1388.

Morisset, J., Neso, O.L., 2002. Administrative barriers to foreign investment in developing countries. World Bank Policy Research Working Paper No. 2848.

Ruane, F., Uğur, A., 2004. Foreign direct investment and productivity spillovers in Irish manufacturing industry: evidence from firm level panel data. International Journal of the Economics of Business 53-66.

Russo, G., Hassink, H.J.W., Gorter, C., 2005. Filling vacancies: an empirical analysis of the cost and benefit of search in the labour market. Applied Economics 37, 1597-1606

UNCTAD, 2007. World Investment Report, Geneva.

Vanhala, J., 2004. Matching Efficiency and Two-Sided Heterogeneity, Ph.D. Dissertation, University of Helsinki. 